\title{
Bioactive Compounds in Organic Sweetpotato
}

\author{
Sochinwechi Nwosisi, Dilip Nandwani*, and Ramasamy Ravi \\ Department of Agriculture and Environmental Sciences, College of Agriculture, Human and Natural Sciences, \\ Tennessee State University, Nashville TN, 37209 USA \\ *Email: dnandwan@tnstate.edu
}

\begin{abstract}
Bioactive compounds in foods have gained popularity worldwide for beneficial effects on human wellbeing. Opportunities for a bioactive food or component, for diet, begin with identifying a link between a bioactive food or ingredient and health or to a disease. The role of bio-actives in health has been established with many research findings. At present bioactive components that promote weight management and lower the risk of obesity, diabetes, and cardiovascular disease have received the most attention. Sweetpotato contains various types of bioactive compounds such as phenolic compounds and carotenoids. Phenolic compounds that are found in sweetpotato include phenolic acids and anthocyanins, which are predominant in purple-flesh sweetpotato. Carotenoids, such as $\alpha$-carotene, $\beta$-carotene, and $\beta-5$ cryptoxanthin are predominant in orange-fleshed sweetpotato. Sweetpotato is rich in dietary fiber, minerals, vitamins and bioactive compoundls such as betacarotene, phenolic acids and anthocyanins which provide sweetpotato with distinctive flesh colors like cream, yellow, orange and purple.
\end{abstract}

Keywords: Carotenoids, dietary phytochemicals, organic agriculture, root crop, vitamins

\section{$1 \quad$ Introduction}

Bioactive elements in plants can be described as secondary substances drawn out from plants induce pharmacological or toxicological result on an individual and animals [1]. NIH defines bioactive compounds as constituents in foods or dietary supplements, other than those needed to meet basic human nutritional needs, are responsible for changes in health. While nutrients draw out pharmacological or toxicological results when consumed in excessive doses (e.g. vitamins and minerals), nutrients in plants are normally not considered in the term bioactive plant component [1]. Plants with powerful bioactive compounds are often typified as both toxic and therapeutic, anı an advantageous or unfavorable outcome may be determined by the quantity taken in and the circumstance of intake but for characteristic plants that give nourishment the food taken into the body are normally considered to be favorable [1]. Sweetpotato is abundant in dietary fiber, minerals, vitamins and compounds of substances with biological effect such as $\beta$-carotene, phenolic acids and anthocyanins that give sweetpotato its unique flesh colors (cream, yellow, orange and purple) [2] refer Fig. 1.

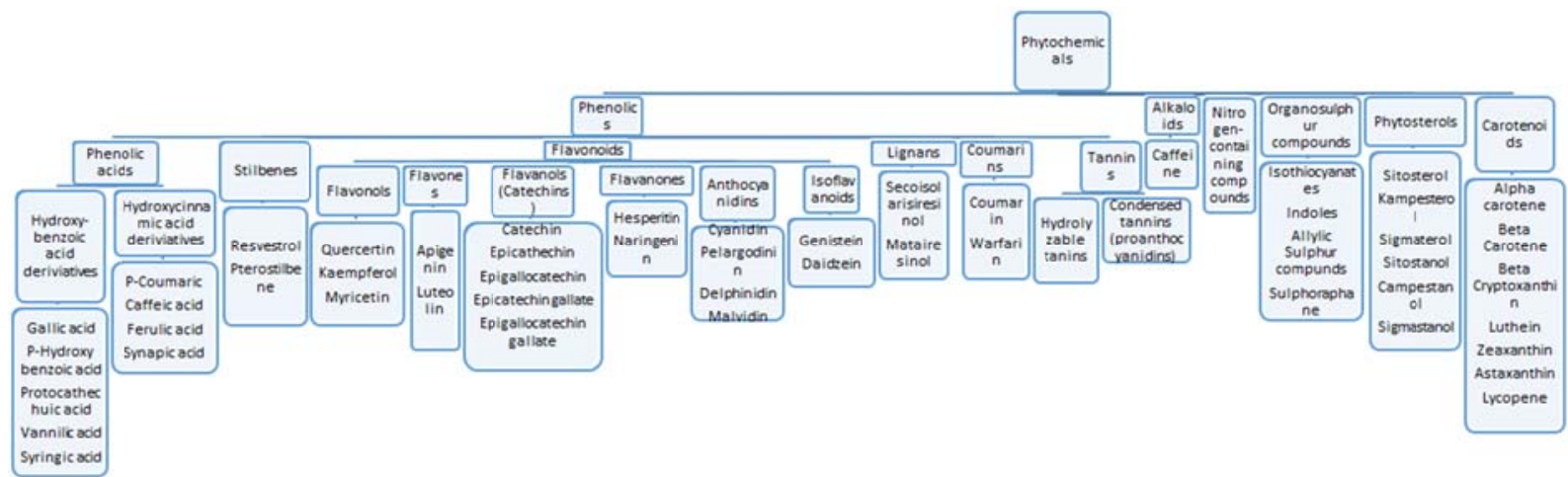

Figure 1. Classification of dietary phytochemicals.

Source: Liu, 2016 (as adapted from Liu, 2004 with permission) 
These bioactive compounds behave as unimpeded progressive scavengers and also pitch in towards the characteristic colors of sweetpotato [2]. Vitamins like vitamin $\mathrm{C}$ and $\mathrm{E}$ also ingrained inside the root [2].

The term "organic agriculture" signifies an agrarian system of production that neither permits the use of chemical pesticides nor synthetic fertilizers. It prohibits the use of genetically modified organisms and requires a lot of labor. Organic farming has gathered a large amount of awareness over the past few years. Since the 1980s, organic farming has experienced constant development, and has lately gathered a greater intensity worldwide [3]. In other for a farm to be certified organic, the farmer has to meet and adhere to specific cultivation standards. The soil is made healthy through use of organic fertilizers if needed, tillage/cultivation practices, crop rotation, use of cover crops, and utilization of plant or animal unwanted substances [4]. There are a number of components that might influence the framework of bioactive compounds, including both changes in the environment and on farm management practices (See figure 2), that need to be considered when comparing food crops cultivater in the organic and conventional systems [5].

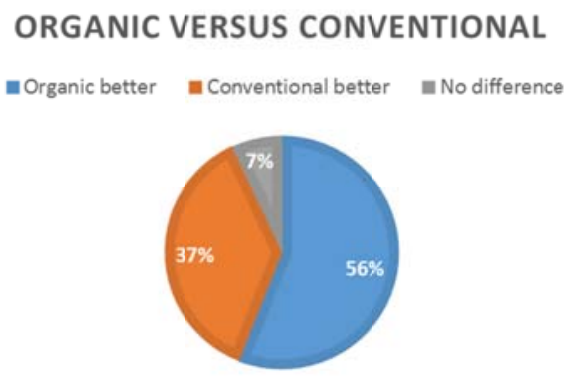

Figure 2. Diagram comparing nutrient levels in organic and conventional crops

*Percent of 1230 published comparisons where nutrient levels are better, worse or the same. The organic crop has the higher nutrient level or lower toxic level in 56 percent of the comparisons while the conventional crop was better only 37 percent of the time [6] Source: Worthington [6]

In conventional farming, large amounts of nitrogen applied to the plant through chemical fertilizers leads the plant to build up more nitrates, smaller amounts of vitamin $\mathrm{C}$ and substandard protein quality [6]. The addition of pesticides to the conventional grown plants to safe-guard those from pathogens may provide an explanation for why they possess less secondary metabolites [5]. Pesticides have been recognized to influence plant make-up, and some research studies have been performed to examine the nutritional outcome [6]. For example, salicylic acid, a polyphenol compound synthesized in reaction to disease causing plant pathogens, normally found in less quantity in all levels of plants, was discovered to be six times greater in organic leafy green broth than in soups prepared from conventionally grown leafy greens [7]. Herbicides are specifically unpleasant as they annihilate plants by making changes to their manufacture of essential compounds such as beta-carotene, tocopherols and annino acids, which all possess nutritional importance [6]. Modern research results have exhibited that organic management system has a greater probability of creating food plants with greater magnitude of secondary metabolites, higher amounts of vitamin C, and higher levels of dry matter (lower water content) [5]. Dangour et al. [8], taking an aggregate of 3558 studies noted the similarity and dissimilarity between the nutrient content including other substances in organically and conventionally grown food materials extracted for analysis. The results from this study reported published that phytochemicals, phenolic compounds and flavonoids was more in organic crop. Worthington, [6] also obtained similar results (see Figure 3).

It is noteworthy that to date limited studies exist in the literature on various sweetpotato types grown in organic system and their total antioxidant capacity in relation to phytochemical content/composition. This paper serves as a review to consolidate literature on the findings on sweetpotato thus far. 


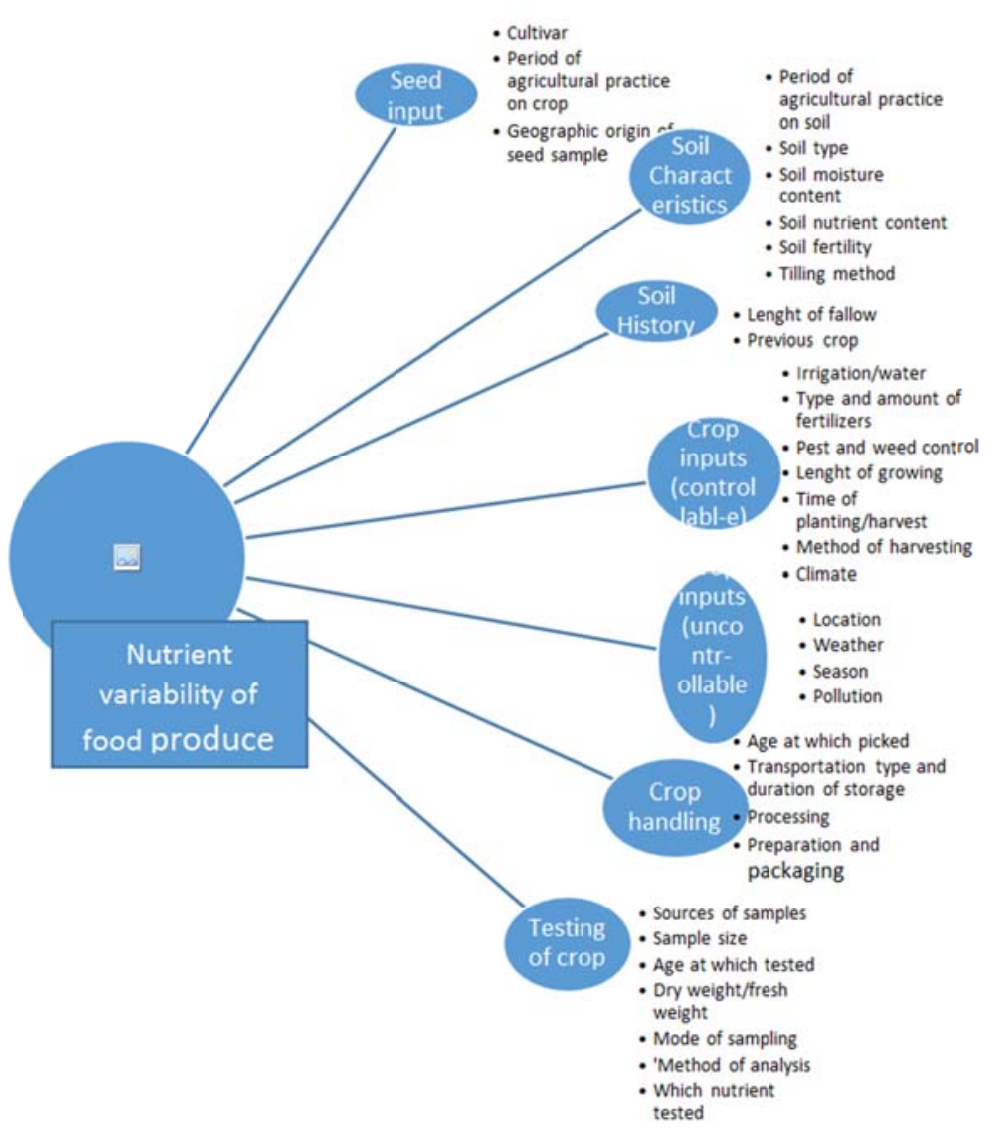

Figure 3. Conceptual framework outlining factors affecting nutrient variability in crops

Source: Dangour et al. [8] with permission

\section{Key Bioactive Compounds in Organic Sweetpotato}

\subsection{Polyphenols and Flavonoids (Anthocyanins)}

Polyphenolic compounds are separated into two main categories: phenolic acids and flavonoids [9]. Phenolics are molecules that inhibit oxidation with no less than a single aromatic ring and single or multiple hydroxyl classes [10]. Flavonoids consist of anthocyanins amongst others which are water soluble [11]. In an investigation by Zhu et al. [12] important anthocyanins were established as peonidin or cyaniding 3-sophoroside-5-glucoside and their derivatives with an acyl group, e.g., peonidin 3sophoroside-5-glucoside, peonidin 3-(6"-p-feruloylsophoroside)-5-glucoside, peonidin 3-(6'- $p$ feruloylsophoroside, and cyanidin 3-(6"-p-feruloylsophoroside)-5-glucoside and main hydroxycinnamic acid derivatives were identified as mono and dicaffeoylquinic acids (e.g., 5-O-Caffeoylyquinic acid and 3,5-di-O-caffeoyl-hexoside. These major phenolic compounds were recognized to be principal contributors overall to proportions of the antioxidant in the assessed sweetpotato roots [12]. Measured evaluations by Salawu et al. [13] expressed caffeic acid (2.97\%) as the most abounding phenolic: compound in purple and white skin of sweetpotato while catechin $(0.17 \%)$ and rutin $(0.17 \%)$ in the order mentioned are of the minutest abundance. The study was able to disclose in addition that iso-quercitrin (1.86\%) and quercitrin $(1.79 \%)$ are the most plentiful phenolic compounds in flesh of sweetpotato with purple and white peel [13]. Plants make phenolic compounds for a number of causes, but one of the main purposes is to make plant substances not so much appealing to herbivores, insects, and animals that prey on them [14]. Some research studies have investigated the possibility of chemo-preventive behavior of sweetpotato phenolic extracts $[15,16]$ with the affirmation that it is advantageous for anemia, 
hypertension and diabetes $[17,13]$. Sweetpotato phenolics was discovered to impede the development of human colon, leukemia and stomach cancer cell lines [18], as well as to hamper viruses and fungi from growing in vitro [19] and to improve diabetes in man [20].

A lot of work has been done to determine the phenolic content in sweetpotato roots in the traditional farming system. In a study by Islam et al. [21] the phenolic contents in sweetpotato roots were observed to be lesser than the numbers 1.42-17.2 g/100g DW assessed in sweetpotato leaves. According to an experiment by Teow [2] the total phenolic content was more, $79.2 \mathrm{mg}$ CAE/100g FWB, for NC- 415 (purple-flesh) and lesser, $0.3 \mathrm{mg}$ CAE/100g FWB for Xushu 18 (white-flesh) sweetpotato root. In general, purple-fleshed sweetpotato genotype was observed to have the greatest phenolic content followed by orange, yellow and white-fleshed [2]. The comprehensive anthocyanins content of the sweetpotato tested varied between 1.32 to $113 \mathrm{mg} / 100 \mathrm{~g}$ sample FWB [2]. Tainung 73 a purple-fleshed sweetpotato (PFSP) was found to have roots loaded with antioxidative compounds, like phenolics, flavonoid, and anthocyanins largely clustered in its skin than flesh [22]. Ji et al. [23] established that purple fleshed sweetpotato (Jizi 01) carried more anthocyanins content $(6.23 \mathrm{mg} / \mathrm{g}$ dry matter) than Xinong 431 (red-flesh $2.56 \mathrm{mg} / \mathrm{g}$ DW) and Beijing 553 (yellow-flesh $1.32 \mathrm{mg} / \mathrm{g}$ DW) while the whitefleshed sweetpotato (Shangshu 19 -showed undetectable value). The designated sequence of the entire phenolic content was Jizi $01(54.3 \mathrm{mg} / \mathrm{g} \mathrm{DW})>$ Xinong $431(25.7 \mathrm{mg} / \mathrm{g} \mathrm{DW})>$ Beijing $553(17.8 \mathrm{mg} / \mathrm{g}$ DW) > Shangshu $19(9.6 \mathrm{mg} / \mathrm{g}$ DW) [23]. It is interesting to note that polyacylated anthocyanins were singled out as the key scavenger of all bioactive compounds discovered in the purple-fleshed sweetpotato $[24,25,26]$.

Cisneros-Zevallos and Cevallos-Casals [27] in their study, announced the anthocyanin content of redfleshed sweetpotato to be $182 \mathrm{mg}$ anthocyanin/100g FW. Moumouni et al. [28] conducted an experiment with eight orange fleshed sweetpotato varieties in Burkina Faso and discovered significant differences (P $<0.05$ ) between their total polyphenolic content fluctuating between 1.06 (BF82xTIB-4) to 2.43 (BF92xResisto-14) mg equivalents of Gallic acid (GAE) /g dry weight. Relatively, higher to lower total phenolic content in nine orange fleshed sweetpotato varieties in a Bangladeshi study by Mohammad et al. [29] was organized in the following order: BARI SP $7>$ BARI SP $4>$ BARI SP $5>$ BARI SP $9>$ BARI SP $2>$ BARI SP $8>$ BARI SP $3>$ BARI SP $1>$ BARI SP 6 . The data collated depicted that total polyphenol content differed ranging between 94.63 to $136.05 \mathrm{mg}$ gallic acid equivalent (GAE)/100 $\mathrm{g}$ fresh weight $(\mathrm{FW})$. Poungmalee, [30] established the total phenolic content in an orange fleshed sweetpotato variety (T101) cultivated in Thailand as $1.94 \mathrm{mg}$ GAE/g of fresh root weight (FW). Teow et al. [31] found the phenolic contents of hand-peeled orange fleshed sweetpotato cultivars grown in the U.S. varied between 0.06 to $0.23 \mathrm{mg}$ GAE/g FW while Walter and Purcell in [32] found them to contain 117 to $467 \mathrm{mg}$ of chlorogenic acid equivalent/kg of fresh weight (FW). Walter and Purcell [32] had also outlined that total phenolic content was extensively different among tested sweetpotato of varying genotypes with the largest quantity being $75 \mathrm{mg}$ CAE/100g FWB. Total phenolic content, measured in terms of chlorogenic acid equivalent, in independent sweetpotato clones fell within 1.4 to $4.7 \mathrm{mg} / \mathrm{g}$ dry weight (DW) according to a published study by Padda and Picha in [33]. Chlorogenic acid and 3,5dicaffeoylquinic acid was the paramount phenolic acid, while caffeic acid was the smallest in amount in many of the sweetpotato roots observed [33]. Chlorogenic acid (422.4 mg/g DW) was the greatest in a white-fleshed cultivar 'Quarter Million' brought in from Jamaica and a purple-flesh sweetpotato root '02-814' had the most quantity of 3,5-dicaffeoylquinic (485.6 mg/g DW), 3,4-dicaffeoylquinic (125.6 $\mathrm{mg} / \mathrm{g} \mathrm{DW}), 4,5$-dicaffeoylquinic $(284.4 \mathrm{mg} / \mathrm{g} \mathrm{DW}$, and caffeic $(20.5 \mathrm{mg} / \mathrm{g} \mathrm{DW})$ acids [33]. Among all orange-fleshed genotypes tested by Padda and Picha [33], 'Diane' possessed the most chlorogenic acid while 'Rubina' had the most quantity of 3, 5-dicaffeoylquinic acid. Meanwhile, of six orange-fleshed varieties measured by Walter and Purcell in [32] the total and individual phenolic acid content was greatest in 'Australian Canner' and least in 'Centennial'.

Yayuan et al. [11] unearthed that in contrast to their fresh sweetpotatoes, the total phenolic content (TPC) of sweetpotato roots processed by heat application (i.e. boiling, steaming and roasting) diminished markedly. The total phenolic content of $15.8 \pm 0.44,12.9 \pm 0.25$ and $11.5 \pm 0.29 \mathrm{mg}$ GAE/g was depicted in the deep purple sweetpotato root specimen prepared by steaming, roasting and boiling, respectively while for yellow sweetpotato samples, the TPC of boiled was $2.28 \pm 0.12 \mathrm{mg}$ $\mathrm{GAE} / \mathrm{g}$, roasted was $3.01 \pm 0.18$, and the steamed was recorded as $3.91 \pm 0.17 \mathrm{mg}$ GAE/g [11]. Furthermore, anthocyanins were discovered to be available in steadier structures in the roasted sweetpotato [11]. The prepared blend of the purple-flesh sweetpotato has a striking reddish-purple color 
with lofty amounts of anthocyanins and total phenolics [34]. The creamy smooth substance made from crushed sweetpotato roots has a firm and stable content of $18 \%$ made from this material with total phenolic and anthocyanin contents of $314 \mathrm{mg}$ chlorogenic acid equivalent/100g FWB and $58 \mathrm{mg}$ cyanidin-3-glucosdie equivalent/100g FWB [34]. As it is comparatively inexpensive to produce sweetpotatoes in relation to other agricultural crops, colored sweetpotatoes may provide a prospective fount of natural anthocyanins for application in food manufacture and processing [35]. While taking into consideration the antioxidant content in organic sweetpotato varieties with various pigments and their corresponding advantages to health, more assessments and research studies should be put in place. As no studies were found on total phenolic content in organic sweetpotato varieties, more research is needed.

\subsection{Vitamin A and Carotenoids}

The orange-fleshed cultivars are presumed to be one of the least costly, abundant, all round season derivation of provitamin A [36]. White or vellow-fleshed sweetpotato, mostly found in Africa, has only a little quantity of provitamin A [36]. Kareem et al. [37] in an on farm research experiment conducted in Ibadan discovered Vitamin A production was greatest in sweetpotato roots cultivated in plots treated with organic fertilizer and least in inorganic fertilizer plots. Resisto variety an orange-fleshed sweetpotato, grown in South Africa, was observed to have between 1,170 and 1,620 Retinol Activity Equivalents (RAE) per $100 \mathrm{~g}$ in its boiled roots and is calculated to supply $25 \%$ to $35 \%$ of the everyday amount permitted for a preschool child [36]. Carotenoids are compounds discovered in plants that can improve the immune response, well-being of humans and can lessen the chances of exposure to diseases that can result in progressive loss of function of organs or tissues such as: cancer, cataracts, cardiovascular diseases. The biological attributes of carotenoids have been linked to their antioxidant properties, precisely their capacity to extinguish unpaired oxygen in such a way that allows them to have an effect on free radicals [9]. $\alpha$-carotene, $\beta$-carotene, $\gamma$-carotene, $\varepsilon$-carotene and lycopene compose carotenoids [38]. $\beta$-carotene gives the sweetpotato root its cream and orange color [2]. The main task of beta-carotene is to act as a vitamin precursor (provitamin A) [38] which the body changes into vitamin A through metabolism. Carotenoids have been examined to bestow health advantages against various types of illnesses such as are associated with age, cancer, stroke, cataracts and other eye problems [39, $40,41]$.

In an in Hawaiian study of eighteen varieties, sweetpotatoes were discovered to possess $13.1 \mathrm{mg} / 100 \mathrm{~g}$ (FWB) of $\beta$ carotene in orange fleshed varieties [42]. $\beta$-carotene content was not present in the whitefleshed varieties 'Mugande' and 'Rutambira 4-160' while the yellow varieties 'Kwizekumwe' (1.85 $\mathrm{mg} / 100 \mathrm{~g} \mathrm{FWB}$ ) and '440170' (1.68 mg/100 g FWB) contained $\beta$ carotene [42]. Beta-carotene content in light yellow and purple fleshed ones were in the range of $0.1-0.6 \mathrm{mg} / 100 \mathrm{~g}$, fresh weight (FW) in a study reported by Lund and Smooth in [43]. Fonseca et al. [44] examined the orange-fleshed sweetpotato root (IAPAR 69) manufactured through the organic system production system and discovered 10,120 $\mu \mathrm{g}$ per $100 \mathrm{~g}$ (d.b.), calculated in $\beta$-carotene equivalent. Meanwhile, Do Nascimento et al. [45] reported 3182 $\mu \mathrm{g}$ of $\beta$ - carotene per 100 grams in organic sweetpotato roots of the orange flesh type. In a study by Donado-Pestana et al. [46], sweetpotato variety produced higher carotenoid levels (7910-12850 $\mathrm{\mu g} / 100 \mathrm{~g}$ db.). Carotenoid content of the orange-fleshed organic sweetpotato flour was established as 2195 $\mu \mathrm{g} / 100 \mathrm{~g}$ solids [45] of which a comparatively close finding was reported by Waramboi et al. (2013) for extruded and non-extruded flour of sweetpotato (2300-35500 $\mu \mathrm{g} / 100 \mathrm{~g}$ solids). Do Nascimento et al. [45] noticed the flour processing of the organic sweetpotato root affected the carotenoid content of orange fleshed cultivar (about 31\%) greatly. Beta-carotene was not determined in the white cultivars. In establishment of total carotenoid (TCC) of sweetpotato that had been processed by heat in different ways, the roasted had the lowest carotenoid contents while the boiled sweetpotato had the highest level [11]. In uncooked sweetpotatoes, the proportion of trans- and cis-b-carotene differed between 76.56-96.49\% and 3.50-23.44\%, in the order mentioned, while in the boiled samples, amount of trans- and cis-bcarotene varied within 61.28 to $95.29 \%$ and 4.71 to $38.72 \%$, respectively [47]. This outcome suggests that boiling sweetpotato causes trans-b-carotene to diminish and cis-b-carotene to rise [47]. Broadly speaking, cis-b-carotene content negligible in sweetpotato roots, however, white- or yellowish-fleshed varieties possess a lot more cis-b-carotene than the orange-fleshed variety [48] depicting how likely carotenoids are to be influenced by heat and broken down and the impact of color of the sweetpotato roots on the carotenoid content. 
Journal of Advances in Molecular Biology, Vol. 1, No. 2, September 2017

Nedunchezhiyan et al. [49] that applying farm yard manure increased b-carotene content in sweetpotato, relative to roots cultivated in land were no fertilizer was applied. Increase in broiler litter influenced some aspects of nutritional quality in organically grown Beauregard sweetpotatoes [50]. The least broiler litter application $0.5 \mathrm{t} \mathrm{ha}^{-1}$ on organically produced sweetpotato yielded highest $(263 \mathrm{\mu g} / \mathrm{g})$ b-carotene content [50]. Organic sweetpotato provided with broiler waste given at one tonne per ha $\mathrm{h}^{-1}$, had the lowest quantity of b-carotene $(139 \mu \mathrm{g} / \mathrm{g})$, increasing slowly with greater increase in broiler litter rate [50]. Grace et al. [51] declared that carotenoid content changes with variety and growing environment in an experiment that indicated concentrations of $\beta$-carotene and total carotenoids to be 25330 and $28190 \mu \mathrm{g} / 100 \mathrm{~g}(\mathrm{db}$.), in orange-fleshed roots of the Covington genotype.

\subsection{Vitamin C}

Although vitamin A and B are present in little quantity in sweetpotato, the roots have plentiful amount of vitamin C [42]. By employing voltammetric and titrimetric methods, Ogunlesi et al. [52] established the vitamin $\mathrm{C}$ content in sweetpotato to be 6.15 and $4.28 \mathrm{mg} / 100 \mathrm{~g}$, while in another study, Watada and Tran [53] discovered it to be $27.7 \mathrm{mg} / 100 \mathrm{~g}$, on fresh weight basis (FWB). In the study by Gichuhi et al. [50], vitamin $\mathrm{C}$ content of the organic sweetpotatoes reached its peak when $0.5 \mathrm{t} \mathrm{ha}^{-1}$ broiler $^{-1}$ manure was added to the growing environment and then steadily reduce as the broiler litter rate rose to $3 \mathrm{t} \mathrm{ha}^{-1}(7.57 \mathrm{mg} / 100 \mathrm{~g})$. Xu et al. [54] indicated that soil fertilization method/type affected the vitamin $\mathrm{C}$ content of crop. Hence, it is most likely that an increase in nitrogen levels due to an increased broiler litter rate is the cause of the quadratic correlation as increased concentration has been reported to result in reduced vitamin $\mathrm{C}$ levels [55]. The study by Aywa et al. [56] measured the quantity of vitamin A and $\mathrm{C}$ in uncooked and boiled varieties of sweetpotato from Vihiga County. The uncooked orange fleshed varieties had higher levels of vitamins than the boiled ones. The sweetpotato varieties tested consisted of vitamin $\mathrm{C}$ within the levels of $4.85 \mathrm{mg} / 100 \mathrm{~g}$ to $5.73 \mathrm{mg} / 100 \mathrm{~g}$ which reduced after boiling to about 0.88 $\mathrm{mg} / 100 \mathrm{~g}$ [56]. An assorted mix of processing methods has been ascribed to be responsible for the breakdown of the vitamin such as baking, frying and boiling $[55,57]$. While more research is needed, the collective discoveries gathered from this review further encourage the use of sweetpotato to solve problems on lack of adequate nourishment.

\subsection{Protein}

Proteins from plants are essential materials in food and plant proteins and peptides with bioactivity also exist [1]. Amino acids are taken in gradually through the intestines and are modified into proteins [1]. According to Teow, [2] the protein content is comparatively low, about $5 \%$ of the dry weight of sweetpotato. Protein component in the white fleshed organic sweetpotato (Capivara and Rosinha de Verdan) cultivars was established to be greater in quantity (2.53 and $1.76 \%$ per dry basis) than that in the orange fleshed $(0.58 \%$ per dry basis) according to Do Nascimento et al. [45]. There was a reduction in the processed flour of the cultivars with the white fleshed (0.99 and $0.67 \%$ per dry basis) and the orange fleshed (0.13\% per dry basis) [45]. Flour from five organic sweetpotato varieties was investigated in a research study by Anthony et al. [58] and the organic sweetpotato varieties established a protein variation between 5.02 to $4.45 \%$. Organic sweetpotato varieties 'SLIPOT/003' (orange flesh) and 'NGB/SP/083' (white flesh) displayed values within the average protein content with suitable functional properties and thus have likelihood to provide nourishment and necessary for healthy growth and living for future generations to come if combined to make a balanced diet [58]. Ji et al. [23] observed that protein content of Shangshu 19 (6.53\% DWB) (white fleshed) was the highest followed by Jizi 01 (6.41\% DWB) (purple fleshed) and Xinong 431 (6.32\% DWB) (red fleshed). The yellow fleshed sweetpotato Beijing 553 (4.86\%DWB) had the least protein content. Few studies that looked at how herbicides affect plant protein content, all reported a reduction in protein quality of the crop with herbicide application [6] another supporting factor for production of sweetpotato using an organic management system.

The protein content of orange fleshed sweetpotato varieties varied between $1.91 \% \pm 1.01 \%$ to $5.83 \%$ $\pm 0.30 \%$ in a study by Mohammad et al. [29]. Villareal et al. [59] found $2.8 \%$ (FWB) protein in the sweetpotato, while Senanayake et al. [60] discovered it to differ between $1.2 \%$ and $3.3 \%$ on a (DW). Eleazu and Ironua, [9] established the quantity of crude protein in the TIS/87/0087 variety of sweetpotato to be $2.67 \%(\mathrm{FW})$ or roughly about $6.00 \%$ (DW) which was a lot more than $1.5 \%$ (FWB) 
or $5 \%$ (DWB) noted to be the raw protein content of sweetpotato [61, 62]. Utilizing the sweetpotato root as a source of plant protein is promising as its consumption could help establish and build regulatory substances which control a variety of body functions such as growth and development, restoration and repair and maintenance of body tissues [9].

\section{Conclusions}

The organic sweetpotato varieties of varying flesh colors have specific phytochemical constituent that makes them great potential agents in improving human health and in food development. Sweetpotato showed improved root nutrient quality when optimum quantity of nitrogen was given through organic materials higher dry matter, vitamin $\mathrm{C}$, and b-carotene, was firmer texture with richer color showing potential for reduced production costs and surface/ground water contamination. Processing of sweetpotato root into flour or by thermal cooking methods, reduces the levels of bioactive components, consequently vitamin A and C quantity as well as protein content. Sweetpotato e.g. purple-fleshed sweetpotato (PFSP) has high levels of antioxidants in them such as phenolics, flavonoid, and anthocyanins largely clustered in its skin than flesh. Red flesh sweetpotato is rich in polyphenols. White fleshed sweetpotato has lycopene and more protein than the orange fleshed. Although cis beta carotene is present in small amounts in sweetpotato roots, it is greater in the yellow and white flesh than the orange flesh. The yellow and orange fleshed sweetpotato contains higher amounts of beta carotene. Studies varied in the levels of bioactive components found in organic sweetpotato varieties cultivated in various parts of the world. More research is needed on nutritional, sensory and health benefit studies on the bioactive components phytochemicals in various cultivars of organic sweetpotato. Further research would also be useful on particular factors and methods in organic crop production and how they would influence plant growth and makeup including the content of secondary bioactive metabolites.

\section{References}

1. B. Aksel, "A brief review on bioactive compounds in plants," in Bioactive compounds in plants - benefits and risks for man and animals, 2010. Proceedings from the Norwegian Academy of Science and Letters, Oslo, 13-14 November, 2008.

2. C. C. Teow, "Antioxidant activity and bioactive compounds of sweetpotato," Master of Science Food Science (thesis). North Carolina State University, Raleigh. 2006. Available: https://repository.lib.ncsu.edu/bitstream/ handle/1840.16/645/etd.pdf?sequence=1\&isAllowed=y.

3. M. Stolze and N. Lampkin. "Policy of organic farming: rationale and concepts" Food Policy. vol. 34, pp. 237-244, 2009.

4. USDA National Organic Program, "Soil fertility and crop nutrient management practice standard," 2013, 7 CFR Section 205.203, Available: www.ams.usda.gov/nop (accessed April 25, 2013).

5. H. Gerd, "Increased levels of bioactive compounds in organically grown food plants. Possible health effects?" in Bioactive compounds in plants - benefits and risks for man and animals, 2010. Proceedings from the Norwegian Academy of Science and Letters, Oslo, 13-14 November, 2008.

6. V. Worthington, "Nutrition and Biodynamics: Evidence for the Nutritional Superiority of Organic Crops," Biodynamics, vol. 224, Jul/Aug 1999. Available: http://soilandhealth.org/wp-content/uploads/01aglibrary/ Arun/V\%20Worethington.pdf

7. G. J. Baxter, A. B. Graham, J. R. Lawrence, "Salicylic acids in soups prepared from organically and nonorganically grown vegetables," European Journal of Nutrition, vol. 40, no. 6, pp. 289-292, 2001.

8. A. Dangour, S. Dodhia, A. Hayter, M. A. Aikenhead, E. Allen, K. Lock, and R. Uauy, "Comparison of composition (nutrients and other substances) of organically and conventionally produced foodstuffs: a systematic review of the available literature," Food Standard Agency. London: London School of Hygiene \& Tropical Medicine, 2009.

9. C. O. Eleazu and C. Ironua, "Physicochemical composition and antioxidant properties of a sweetpotato variety (Ipomoea batatas L) commercially sold in South Eastern Nigeria," African Journal of Biotechnology, vol. 12, no. 7, 2013. 
10.Y. L. Shen, P. Jin, Xiao, et al., "Total phenolics, flavonoids, antioxidant capacity in rice grain and their relations to grain color, size and weight," Journal of Cereal Science. vol. 49, pp. 106-111, 2009.

11.T. Yayuan, C. Weixi, and X. Baojun, "Profiles of phenolics, carotenoids and antioxidative capacities of thermal processed white, yellow, orange and purple sweetpotatoes grown in Guilin, China," Food Science and Human Wellness. vol. 4, no. 3, pp. 123-132, 2013.

12.F. Zhu, Y. Z. Cai., X. Yang, J. Ke, and H. Corke, "Anthocyanins, hydroxycinnamic acid derivatives, and antioxidant activity in roots of different Chinese purple-fleshed sweetpotato genotypes," Journal of agricultural and food chemistry, vol. 58, no. 13, pp. 7588-7596, 2010.

13.S. O. Salawu, E. Udi, A.A. Akindahunsi, A.A. Boligon, and M.L Athayde, "Antioxidant potential, phenolic profile and nutrient composition of flesh and peels from Nigerian white and purple skinned sweetpotato (Ipomea batatas L.)," Asian Journal of Plant Science and Research, vol. 5, no. 5, pp. 14-23, 2015.

14.R. C. Theuer, "Do organic fruits and vegetables taste better than conventional fruits and vegetables?" State of the Science Review: Taste of organic food. The Organic Center, 2006, Available: www.organic-center.org.

15.H. M. Shimozono, H. Kobori, T. Shinmoto, and J. Tsushida, "Suppression of the melanogenesis of mouse melanoma b-16 cells by sweet-potato extract," The Japanese Society for food science and technology., vol. 43, pp. 313-317, 1996.

16.I. O. Rabah, D. X. Hou, S. I. Komine, and M. Fujii. "Potential chemo-preventive properties of extract from baked sweetpotato (Ipomoea batatas Lam. cv. Koganesengan),".Journal of Agricultural and Food Chemistry, vol. 52, pp. 7152-7157, 2004, doi: 10.1021/jf049368w.

17.B. Ludvik, B. Neuffer, and G. Pacini, "Efficacy of Ipomoea batatas (Caiapo) on diabetes control in type 2 diabetic subjects treated with diet," Diabetes Care, vol. 27, no. 2, pp. 436-440, 2004.

18.R. Kurata, M. Adachi, O. Yamakawa, and K. Yoshimoto, "Growth suppression of human cancer cells by polyphenolics from sweetpotatoes (Ipomoea batatas L.) leaves," Journal of agricultural and Food Chemistry, vol. 55, pp. 185-190, 2007.

19.J. K. Peterson, H. F. Harrison, M. E. Snook, and D. M. Jackson, "Chiorogenic acid content in sweetpotato germplasm: Possible role in disease and pest resistance," Allelopathy Journal, vol. 16, pp. 239-249, 2005.

20.B. Ludvik, M. Hanefeld, and G. Pacini, "Improved metabolic control by Ipomoea batatas (Caiapo) is associated with increased adiponectin and decreased fibrinogen levels in type 2 diabetic subjects." Diabetes, Obesity and Metabolism, vol. 10, no. 7, pp. 586-592, 2008.

21.M. S. Islam, M. Yoshimoto, S. Yahara, S. Okuno, K. Ishiguro, and M. Yoshinaga, "Antioxidative compounds in the leaves of sweetpotato," Research Front, vol. 13, no. 4, 2002.

22.Y.C. Lai., Z. T. Li, T. L. Jeng, and W. H. Tsai, "Breeding of the new sweetpotato variety, Tainung," Journal of Taiwan Agricultural Research, vol. 57, no. 73, pp. 279-294, 2008.

23.H. Ji, H. Zhang, H. Li, and Y. Li, "Analysis on the Nutrition Composition and Antioxidant Activity of Different Types of Sweetpotato Cultivars," Food and Nutrition Sciences, vol. 6, no. 1, pp. 161, 2015.

24.K. Odake, N. Terahara, N. Saito, K. Toki, and T. Honda. "Chemical structures of two anthocyanins from purple sweetpotato, Ipomoea batatas," Phytochemistry, vol. 31, pp. 2127-2130, 1992.

25.Y. Goda, T. Shimizu, Y. Kato, M. Nakamura, T. Maitani, T. Yamada, N. Terahara, and M. Yamaguchi, "Two acylated anthocyanins from purple sweetpotato," Phytochemistry, vol. 44, pp. 33-35, 1997.

26.M. Yoshimoto, S. Okuno, M. Yoshinaga, O. Yamakawa, M. Yamaguchi, and J. Yamada, "Antimutagenicity of sweetpotato (Ipomoea batatas) root," Bioscience, Biotechnology and Biochemistry, vol. 63, pp. 537-541, 1999.

27.B. Cevallos-Casals and L. Cisneros-Zevallos, "Stoichiometric and kinetic studies of phenolic antioxidants from andean purple corn and red-fleshed sweetpotato," Journal of Agricultural and Food Chemistry, vol. 51, pp. 3313$3319,2003$.

28.K. Moumouni, H. Adama, S. Koussao, P. Eloi, S. Abdoulaye, B. Jérôme, and N. Mouhoussine, "Evaluation of Eight Orange Fleshed Sweetpotato (OFSP) Varieties for Their Total Antioxidant, Total Carotenoid and Polyphenolic Contents," Journal of Natural Sciences Research, vol. 3, no. 4, 2013, Available: www.iiste.org ISSN 2224-3186 (Paper) ISSN 2225-0921 (Online).

29.K. A. Mohammad, H. R. Ziaul and N. I. Sheikh, "Comparison of the Proximate Composition, Total Carotenoids and Total Polyphenol Content of Nine Orange-Fleshed Sweetpotato Varieties Grown in Bangladesh," Foods, vol. 5, no. 64, 2016; doi: 10.3390/foods5030064. 
30.B. Poungmalee, "Total Phenolic Content and Antioxidant Activity of Sweetpotato (Ipomoea Batatas L.) Flours from Different Varieties Grown in Thailand," In Proceedings of Pure and Applied Chemistry International Conference (PACCON), Bangsaen, Thailand, January; pp. 23-25, 2013.

31.C. C. Teow, V. D. Truong, R. F. McFeeters, R. L. Thompson, K. V. Pecota, and G. C. Yencho, "Antioxidant activities, phenolic and $\beta$-carotene contents of sweetpotato genotypes with varying flesh colours" Food Chemistry. vol. 103, pp. 829-838, 2007.

32.W. M. Walter and A. E. Purcell, Evaluation of several methods for analysis of sweetpotato phenolics, Journal of Agricultural and Food Chemistry, vol. 27, pp. 942-946, 1979.

33.M. S. Padda and D. H. Picha, "Quantification of phenolic acids and antioxidant activity in sweetpotato genotypes," Scientia Horticulturae, vol. 119, no. 1, pp. 17-20, 2008.

34.T. Van-Den, and A. Ramesh, "Sweetpotato purees and powders for functional food ingredients," In: Sweetpotato: Post Harvest Aspects in Food. Editors: R. C. Ray and K. I. Tomlins. Nova Science Publishers, Inc, New York. pp. 117-161, 2010. Available: https://fbns.ncsu.edu/USDAARS/Acrobatpubs/S114-150/S134.pdf. ISBN 978-160876-343-6

35.M. O. Oke and T. S. Workneh, "A review on sweetpotato postharvest processing and preservation technology," African Journal of Agricultural Research, vol. 8, no. 40, pp. 4990-5003, 2013.

36.S. Albert, "Food and Nutrition Biotechnology: Achievements, Prospects, and Perceptions. 2005," United Nations University, Institute of advanced studies report (UNU-IAS Report). Available: http://www.eldis.org/vfile/ upload/1/document/0708/DOC19681.pdf

37.I. Kareem, "Fertilizer treatment effects on yield and quality parameters of sweetpotato (Ipomoea batatas)," Research Journal of Chemical and. Environmental. Sciences, vol. 1, no. 3, pp. 40-49, 2013.

38.D. Dhianawaty and R. Panigoro, "Antioxidant activity and total weight of carotenoids in red sweetpotato (Ipomoea batatas L.) tuber," International Journal of Research in Pharmacology and Phytochemistry, vol. 3, no. 1, pp. 70-73, 2013.

39.A.V. Rao and L.G. Rao. Carotenoids and human health: Invited review. Pharmacological Research, vol. 55, pp. 207-216, 2007.

40.S. V. Padgaonkar, "Health Benefits of Natural Mixed Carotenoids, "Protein Foods and Nutrition Development Association of India, 2008, Mumbai: Mahalaxmi Chambers.

41.S. S. Kadian and M. Garg "Pharmacological effects of carotenoids: A review," International Journal of Pharmaceutical Science and Research. vol. 3, no. 1, pp. 42-48, 2012.

42.I. M. Rose and H. Vasanthakaalam, "Comparison of the nutrient composition of four sweetpotato varieties cultivated in Rwanda," American Journal of Food and Nutrition, vol. 1, pp. 34-38, 2011.

43.E. Lund and J.M. Smooth, "Dietary Fiber Content of Some Tropical Fruits and Vegetables," Journal of Agricultural and Food Chemistry. vol. 30, pp. 1123-1127, 1982.

44.M. J. O. Foneseca, "Effect of extrusion cooking in total carotenoids content in cream and orange flesh sweetpotato cultivars," Horticultura Brasileira, Brasília, vol. 26, pp. 112-115, 2008.

45.K. D. O. Do Nascimento, D. S. Lopes, C. Y. Takeiti, Jr, J. L. Barbosa, and M. I. M. J. Barbosa, "Physicochemical characteristics of tubers from organic sweetpotato roots," Revista Caatinga, vol. 28, no. 2, pp. 225-234, 2015.

46.C. M. Donado-Pestana, "Stability of carotenoids, total phenolics and in vitro antioxidant capacity in the thermal processing of orangefleshed sweetpotato (Ipomoea batatas Lam.) cultivars grown in Brazil," Plant Foods and Human Nutrition, vol. 67, no. 3, pp. 262-270, 2012.

47.S. N. Islam, T. Nusrat, P. Begum, and M. Ahsan, "Carotenoids and $\beta$-carotene in orange fleshed sweetpotato: A possible solution to vitamin A deficiency," Food chemistry, vol. 199, pp. 628-631, 2016.

48.S. Liu, J. Lin, and D-J. Yang, "Determination of cis and trans- a- and b-carotenoids in Taiwanese sweetpotatoes (Ipomoea batatas (L.) Lam.) harvested at various times," Original Research Article. Food Chemistry, vol. 116, pp. 605-610, 2009.

49.M. Nedunchezhiyan, G. Byju, and S. N. Dash, "Effect of organic production of orange fleshed sweetpotato (Ipomoea batatas L.) on root yield, quality and soil biological health," International Research Journal of Plant Science, vol. 1, pp. 136-143, 2010. 
50.P. N. Gichuhi, A. K. Kpomblekou and A. C. Bovell-Benjamin, "Nutritional and physical properties of organic Beauregard sweetpotato [Ipomoea batatas (L.)] as influenced by broiler litter application rate,” Food science and nutrition, vol. 2, no. 4, pp. 332-340, 2014.

51.M. H. Grace, et al, "Phytochemical changes in phenolics, anthocyanins, ascorbic acid, and carotenoids associated with sweetpotato storage and impacts on bioactive properties," Food Chemistry, London, vol. 145, no. 15, pp. 717-724, 2014.

52.M. Ogunlesi, W. Okiei, L. Azeez, V. Obakachi, M. Osunsanmi and G. Nkenchor. "Vitamin C contents of tropical vegetables and foods determined by voltammetric and titrimetric methods and their relevance to the medical uses of the plants," International Journal of Electrochemical Science, vol. 5, pp. 105-115, 2010.

53.A. E. Watada and T. T. Tran. "Vitamin C, B1, and B2 contents of stored fruits and vegetables as determined by high performance liquid chromatography," Journal of American Society for Horticultural Science, vol. 112, pp. 794-797, 1987.

54.H. L. Xu, R. Wang, M. A. U. Mridha, S. Kato, K. Katase and H. Umemura, "Effects of organic fertilization and EM inoculation on leaf photosynthesis, fruit yield and quality of tomato plants," Journal of crop production. Vol. 3, pp. 173-182, 2001.

55.S. K. Lee and A. A. Kader, "Pre-harvest and postharvest factors influencing vitamin C content of horticultural crops," Postharvest Biology and Technology, vol. 20, pp. 207-220, 2000.

56.K. Aywa, M. P. Nawiri, and H. N. Nyambaka, "Nutrient variation in colored varieties of Ipomea batatas grown in vihiga county, western Kenya", International Food Research Journal, vol. 20, no. 2, pp. 819-825, 2013.

57.O. O. K' Babalola, H. O. Adubiaro, and O. Ikusika, "The effect of some processing methods on vitamin C content of sweetpotatoes and Irish potatoes," Electrical Journal of Environmental, Agricultural and Food Chemistry, vol. 9, no. 4, pp. 679-681, 2010.

58.N. M Anthony, M. K. Sawi, O.O Aiyelaagbe, A. Taiwo, T. Winnebah, and S. N. Fomba, "Proximate characteristics and complementary assessment of five organic sweetpotatoes cultivars and cowpea varieties", The International Journal of Engineering and Science, vol. 3, no. 9, pp. 38-42, 2014.

59.R. L. Villareal, S. C. S. Tsou, S. K. Lin, S. C. Chiu, "Use of sweetpotato leaf tips as vegetables," II. Evaluation of yield and nutritive quality. Experimental Agriculture, vol. 15, pp. 117-122, 1979.

60.S. A. Senanayake, K. K. D. S. Ranaweera, A. Gunaratne, A. Bamunuarachchi, "Comparative analysis of nutritional quality of five different cultivars of sweetpotatoes (Ipomea batatas (L) Lam) in Sri Lanka," Journal of food science and nutrition, vol. 1, pp. 284-291, 2013.

61.J. Bradbury, W. Holloway, "Chemistry of Tropical Root Crops," Australian Centre for International Agricultural Research, Canberra, Australia, 1988, pp. 196

62.J. A. Woolfe, "Sweetpotato an untapped food resource," Cambridge Univ. Press, Cambridge, UK, 1992, P. 60. 